\title{
A Liquid/Liquid-Type Heteropolyanion Reference Electrode for Ion-Transfer Voltammetry
}

\author{
Toshiyuki OsaKaI and Kazuhiro Muto \\ Department of Chemistry, Faculty of Science, Kobe University, Nada, Kobe 657, Japan
}

\begin{abstract}
A new liquid/liquid-type reference electrode for ion-transfer voltammetry with the nitrobenzene (NB)/water (W) interface has been developed. This reference electrode is expressed as Pt/1.8 $\mathrm{mM} \alpha-\left[\mathrm{SiMo}_{12} \mathrm{O}_{40}\right]^{4-}+0.2 \mathrm{mM} \alpha-$ $\left[\mathrm{SiMo}_{2}{ }_{2} \mathrm{Mo}_{12} \mathrm{O}_{40}\right]^{4-}+0.1 \mathrm{M} \mathrm{H}_{2} \mathrm{SO}_{4}(\mathrm{~W}) / 0.3 \mathrm{mM} \alpha-\left[\mathrm{SiMo}_{12} \mathrm{O}_{40}\right]^{4-}+0.02 \mathrm{M}$ tetrahexylammonium tetraphenylborate (NB). The Galvani potential difference between the reference NB/W interface is determined virtually by the distribution equilibrium of the heteropolyanion $\left(\alpha-\left[\mathrm{SiMo}_{12} \mathrm{O}_{40}\right]^{4-}\right)$, whereas the $\mathrm{Pt}$ electrode potential is determined by the redox equilibrium of the heteropolyanion couple. With this reference electrode, a potential window of about $0.4 \mathrm{~V}$ is available in a fairly negative potential region, where the transfer of hydrophilic inorganic anions $\left(\mathrm{Br}^{-}, \mathrm{I}^{-}, \mathrm{SCN}^{-}, \mathrm{NO}_{3}^{-}\right.$, and $\left.\mathrm{ClO}_{4}^{-}\right)$ can be observed voltammetrically.
\end{abstract}

Keywords Reference electrode, ion-transfer voltammetry, 12-molybdosilicate, nitrobenzene/water interface

In recent years the electrochemical technique with the interface between two immiscible liquids, which we call "ion-transfer voltammetry", has been extensively applied to the study of ion-transfer processes in various fields. ${ }^{1-4}$ A typical Galvani cell used in such measurements is shown in the following diagram:

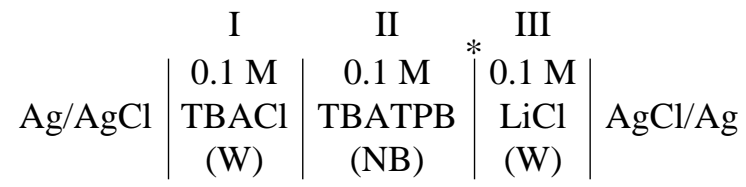

where TBACl and TBATPB stand for tetrabutylammonium chloride and tetrabutylammonium tetraphenylborate, respectively. The nitrobenzene (NB)/water (W) interface (indicated by an asterisk) between phases II and III is polarizable, and when a "semi-hydrophobic" ion like tetramethylammonium ion is added to either phase, its transfer across the interface can be observed voltammetrically. ${ }^{5}$ As also seen in cell $\mathrm{A}, \mathrm{a} \mathrm{Ag} / \mathrm{AgCl}$ electrode is usually used for the reference electrode in the $\mathrm{W}$-phase side. On the other side, since there is no reference electrode which can be used in $\mathrm{NB}^{6}$, such a liquid/liquid (L/L) type reference electrode as in cell $\mathrm{A}$ is generally employed. The Galvani potential difference between phases I and II, $\Delta_{\mathrm{II}}^{\mathrm{I}} \phi\left(\equiv \phi^{\mathrm{I}}-\phi^{\mathrm{II}}\right)$, is determined by the distribution equilibrium of $\mathrm{TBA}^{+}$between the two phases: ${ }^{5,7}$

$$
\Delta_{\mathrm{II}}^{\mathrm{I}} \phi=\Delta_{\mathrm{NB}}^{\mathrm{W}} \phi_{\mathrm{TBA}^{+}}^{\circ} \frac{R T}{F} \ln \frac{a_{\mathrm{TBA}}^{\mathrm{II}}}{a_{\mathrm{TBA}^{+}}^{\mathrm{I}}}
$$

where $\Delta_{\mathrm{NB}}^{\mathrm{W}} \phi_{\mathrm{TB}^{+}}^{\circ}$ is the standard ion-transfer potential of $\mathrm{TBA}^{+}, a_{\mathrm{TBA}^{+}}^{\mathrm{I}}$ and $a_{\mathrm{TBA}^{+}}^{\mathrm{II}}$ are the activities of $\mathrm{TBA}^{+}$in phases I and II, respectively, and $R, T$, and $F$ have their usual meanings. Since the $\mathrm{Ag} / \mathrm{AgCl}$ electrode immersed in an aqueous solution (phase I) containing $\mathrm{Cl}^{-}$ shows a defined potential, the $\mathrm{Ag} / \mathrm{AgCl} / 0.1 \mathrm{M} \mathrm{TBACl}$ (W) electrode finally exhibits a Nernstian response to $\mathrm{TBA}^{+}$in NB (phase II).

Although the above cell system has been frequently utilized, its polarizable potential range (so-called "potential window") is not very wide (i.e., about 0.32 $\mathrm{V})$, because the negative-current limit is determined by the transfer of $\mathrm{TBA}^{+}$that is not sufficiently hydrophobic. Thus far, some attempts have been made to broaden the potential window by replacing $\mathrm{TBA}^{+}$with more hydrophobic cations including Crystal Violet ${ }^{8-10}$, tetraphenylarsonium ${ }^{10,11}$, tetrapentylammonium $\left(\mathrm{TPenA}^{+}\right)^{12}$, and tetrahexylammonium $\left(\mathrm{THexA}^{+}\right)^{12}$ ions. For example, the use of $\mathrm{THexA}^{+}$broadens the polarizable potential range in the negative direction by as much as $c a$. $0.25 \mathrm{~V}^{12}$ In this case, however, such an $\mathrm{L} / \mathrm{L}$ type reference electrode as shown in cell $\mathrm{A}$ is no longer available, because $\Delta_{\text {II }}^{\mathrm{I}} \phi$ is not determined only by the distribution equilibrium of $\mathrm{THexA}^{+} ; \mathrm{Cl}^{-}$added initially to the aqueous phase (phase I) may be extracted to NB by $\mathrm{THexA}^{+}$of extreme hydrophobicity. The $\Delta_{\text {II }}^{\mathrm{I}} \phi$ of the interface should be elucidated on the basis of the concept of the mixed ion-transfer potential ${ }^{13-16}$, and from a practical point of view, it seems inappropriate to use such an interface for a reference interface.

In this paper we will propose a new L/L type reference electrode based on the distribution of a Keggintype heteropoly molybdosilicate anion, viz. $\alpha$ $\left[\mathrm{SiMo}_{12} \mathrm{O}_{40}\right]^{4-}$, at the NB/W interface and its redox equilibrium at the platinum electrode surface. Figure 1 shows the scheme of the new reference electrode. In 


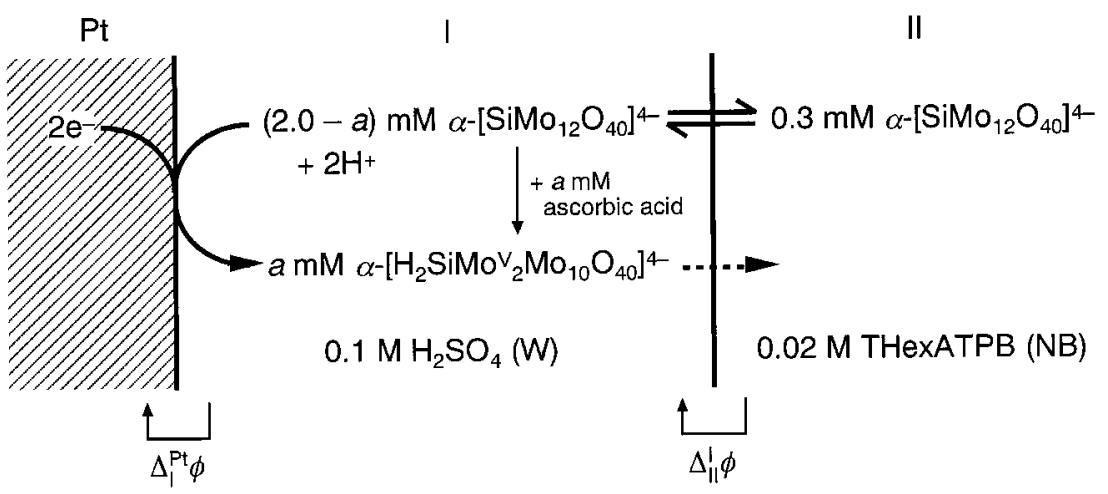

Fig. 1 Scheme of the heteropolyanion reference electrode. To phase I, $2.0 \mathrm{mM} \alpha-\mathrm{H}_{4}\left[\mathrm{SiMo}_{12} \mathrm{O}_{40}\right]$ was initially added, a part of which was then reduced by the addition of $a \mathrm{mM}$ ascorbic acid (usually, $a=0.2$ ). To phase II, the heteropolyanion was added as the THexA+ salt.

this reference electrode system, $\Delta_{\mathrm{II}}^{\mathrm{I}} \phi$ is determined virtually by the distribution of $\alpha-\left[\mathrm{SiMo}_{12} \mathrm{O}_{40}\right]^{4-}$ between phases I and II: ${ }^{17}$

$$
\alpha-\left[\mathrm{SiMo}_{12} \mathrm{O}_{40}\right]^{4-}(\mathrm{W}) \rightleftharpoons \alpha-\left[\mathrm{SiMo}_{12} \mathrm{O}_{40}\right]^{4-}(\mathrm{NB})
$$

On the other side, the potential $\left(\Delta_{\mathrm{I}}^{\mathrm{Pt}} \phi\right)$ of the platinum electrode immersed in the acidic heteropolyanion solution is determined by the equilibrium potential of the redox couple: ${ }^{18,19}$

$$
\begin{array}{r}
\alpha-\left[\mathrm{SiMo}_{12} \mathrm{O}_{40}\right]^{4-}+2 \mathrm{e}^{-}+2 \mathrm{H}^{+} \rightleftharpoons \\
\alpha-\left[\mathrm{H}_{2} \mathrm{SiMo}_{2}{ }_{2} \mathrm{Mo}_{10} \mathrm{O}_{40}\right]^{4-}
\end{array}
$$

In this study the characteristics of the heteropolyanion reference electrode have been evaluated through the use in voltammetric measurements for the transfer of some hydrophilic inorganic anions.

\section{Experimental}

\section{Chemicals}

Based on TG-DTA, 12-molybdosilicic acid $n$-hydrate $\left(\alpha-\mathrm{H}_{4}\left[\mathrm{SiMo}_{12} \mathrm{O}_{40}\right] \cdot n \mathrm{H}_{2} \mathrm{O}\right.$; available from Wako Pure Chemical Industries, Ltd.) was dehydrated by heating at $120^{\circ} \mathrm{C}$ before use. The THexA ${ }^{+}$salt, $\alpha-(\mathrm{THexA})_{4^{-}}$ $\left[\mathrm{SiMo}_{12} \mathrm{O}_{40}\right]$, was prepared as follows: $2 \mathrm{~g}$ of $\alpha-\mathrm{H}_{4^{-}}$ $\left[\mathrm{SiMo}_{12} \mathrm{O}_{40}\right]$ (anhydrous) was dissolved in $44 \mathrm{ml}$ of $1: 1$ (v/v) 1,4-dioxane-water containing 1.0 M sulfuric acid. After $15 \mathrm{~h}$ during which the $\beta$-isomer as an impurity was transformed into the $\alpha$-isomer, $2 \mathrm{~g}$ of THexABr (Tokyo Kasei Kogyo Co. Ltd.) was added to the yellow heteropolyanion solution. The resulting yellow precipitates were collected by filtration and recrystallized from acetone. The salt was finally dried at $50^{\circ} \mathrm{C}$ under reduced pressure.

Tetrahexylammonium tetraphenylborate (THexATPB) was prepared as described previously. ${ }^{12}$ Analytical-grade NB (Wako) was treated by activated alumina (200 mesh) for column chromatography before use. All other reagents were of analytical grade and used as further purification.

Preparation of the heteropolyanion reference electrode The aqueous heteropolyanion solution for phase I (Fig. 1) was prepared by dissolving $2.0 \mathrm{mM} \alpha$ $\mathrm{H}_{4}\left[\mathrm{SiMo}_{12} \mathrm{O}_{40}\right]$ (anhydrous) in $0.1 \mathrm{M}$ sulfuric acid, followed by addition of $a \mathrm{mM}$ ascorbic acid (usually $a=$ 0.2 ) which reduced an equimolar amount of the heteropolyanion as shown in Fig. 1. After standing for at least $30 \mathrm{~min}$, the resulting blue solution was loaded in a Luggin capillary, in which a platinum wire electrode was then inserted. Finally, the reference NB/W interface was formed around the end of the Luggin capillary.

\section{Electrochemical measurements}

All voltammetric measurements were performed with a micro-computer assisted system (laboratory-constructed). Unless otherwise noted, the three-electrode cell previously reported ${ }^{20}$ was employed for ion-transfer voltammetry. For redox voltammetry with a platinum working electrode a conventional three-electrode cell system was used. Potentiometric measurements were performed with an Advantest (Model TR8652) electrometer. All the electrochemical measurements were carried out at $25 \pm 0.1^{\circ} \mathrm{C}$.

\section{Results and Discussion}

\section{Reversibility of the heteropolyanion redox couple}

The reversible behaviors of the redox couple shown in Eq. (3) on the platinum electrode were observed by potentiometric measurements of the electrode potential in $0.1 \mathrm{M} \mathrm{H}_{2} \mathrm{SO}_{4}$ (air saturated) containing $2 \mathrm{mM} \alpha$ $\mathrm{H}_{4}\left[\mathrm{SiMo}_{12} \mathrm{O}_{40}\right]$, to which an aliquot of an ascorbic acid solution $(0.1 \mathrm{M})$ was added stepwise. As we would expect, the equilibrium electrode potential measured against $\mathrm{Ag} / \mathrm{AgCl}($ sat. $\mathrm{KCl})$ was found to obey the Nernst equation : 


$$
\begin{gathered}
E^{\mathrm{e}}=E^{\circ}+\frac{2.303 R T}{2 F} \log \frac{[\mathrm{ox}]}{[\mathrm{red}]} \approx \\
0.280+0.033 \log \frac{[\mathrm{ox}]}{[\mathrm{red}]} \quad(\text { in V) }
\end{gathered}
$$

where $E^{\circ}$ is the formal potential; [ox] and [red] are the concentrations of oxidized and reduced forms of the heteropolyanion. The value of $E^{\circ \prime}(=0.280 \mathrm{~V})$ agreed with that obtained from cyclic and normal-pulse voltammetric measurements.

Ion transfer voltammetry of yellow and blue heteropolyanions at the $N B / W$ interface

The interfacial transfer of the yellow (oxidized) heteropolyanion $\left(\alpha-\left[\mathrm{SiMo}_{12} \mathrm{O}_{40}\right]^{4-}\right)$ has already been studied in rather detail. ${ }^{17}$ In this study, we investigated the transfer of the blue species, i.e., the 2-electron reduced form $\left(\alpha-\left[\mathrm{H}_{2} \mathrm{SiMo}_{2}{ }_{2} \mathrm{Mo}_{10} \mathrm{O}_{40}\right]^{4-}\right)$, which may interfere with the distribution equilibrium of the yellow species in the reference electrode system in Fig. 1. In Fig. 2 the voltammogram of the transfer of the blue species is compared with that of the yellow species. As seen, the transfer potential of the blue species is almost identical with that of the yellow species. The midpoint potential $E_{\text {mid }}^{21}(=0.354 \mathrm{~V})$ of the blue species was only $10 \mathrm{mV}$ more negative than that of the yellow species.

\section{Distribution behaviors of the heteropolyanion at the $N B / W$ interface}

In order to know if the reference NB/W interface (between phases I and II in Fig. 1) exhibits a Nernstian response to $\alpha$-[ $\left[\mathrm{SiMo}_{12} \mathrm{O}_{40}\right]^{4-}$, we have measured the emf

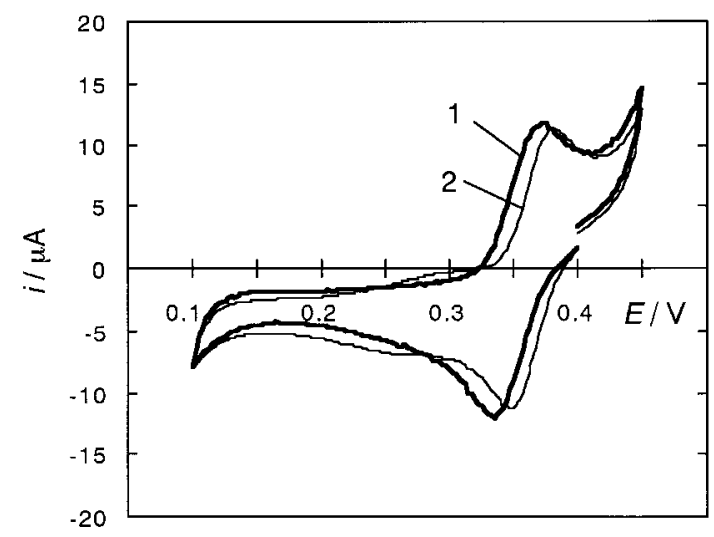

Fig. 2 Cyclic voltammograms of the transfer of (1) $0.2 \mathrm{mM} \alpha$ $\left[\mathrm{SiMo}_{12} \mathrm{O}_{40}\right]^{4-}$ (yellow) and (2) $0.2 \mathrm{mM} \alpha-\left[\mathrm{H}_{2} \mathrm{SiMoV}_{2^{-}}\right.$ $\left.\mathrm{Mo}_{10} \mathrm{O}_{40}\right]^{4-}$ (blue) at the $0.1 \mathrm{M} \operatorname{TPenATPB}(\mathrm{NB}) / 0.5 \mathrm{M} \mathrm{MgCl}_{2}$ $+0.1 \mathrm{M} \mathrm{H}_{2} \mathrm{SO}_{4}(\mathrm{~W})$ interface (area $=0.127 \mathrm{~cm}^{2}$ ). The heteropolyanion was added to the $\mathrm{W}$ phase as the acid form. The blue species (2) was prepared through a reduction of the yellow species by ascorbic acid. Reference electrodes: a $\mathrm{Ag} / \mathrm{AgCl} / 0.02 \mathrm{M}$ TPenACl $+0.1 \mathrm{M} \mathrm{MgSO}_{4}(\mathrm{~W})$ electrode was used in the NB phase, while a $\mathrm{Ag} / \mathrm{AgCl} / 0.5 \mathrm{M} \mathrm{MgCl}_{2}+0.1 \mathrm{M}$ $\mathrm{H}_{2} \mathrm{SO}_{4}(\mathrm{~W})$ electrode was connected to the $\mathrm{W}$ phase through a glass sinter. The cyclic potential scan was applied from $0.4 \mathrm{~V}$ in the cathodic direction at the rate of $50 \mathrm{mV} \mathrm{s}^{-1}$. (electromotive force) of the following cell :

$$
\begin{aligned}
& \text { I II } \\
& \operatorname{Pt} \mid \begin{array}{c|c}
1.8 \mathrm{mM} & 0.3 \mathrm{mM} \\
\alpha-\left[\mathrm{SiMo}_{12} \mathrm{O}_{40}\right]^{4-} & \alpha-(\mathrm{THexA})_{4}\left[\mathrm{SiMo}_{12} \mathrm{O}_{40}\right] \\
0.2 \mathrm{mM} \alpha-\left[\mathrm{H}_{2} \mathrm{SiMo}_{2} \mathrm{Mo}_{10} \mathrm{O}_{40}\right]^{-} & 0.02 \mathrm{M} \mathrm{THexATPB} \\
0.1 \mathrm{M} \mathrm{H}_{2} \mathrm{SO}_{4}(\mathrm{~W}) & (\mathrm{NB})
\end{array} \\
& \text { III } \\
& \left|\begin{array}{c}
0.1-5 \mathrm{mM} \alpha-\left[\mathrm{SiMo}_{12} \mathrm{O}_{40}\right]^{4-} \\
0.2 \mathrm{mM} \alpha-\left[\mathrm{H}_{2} \mathrm{SiMo}_{2} \mathrm{Mo}_{10} \mathrm{O}_{40}\right]^{4-} \\
0.1 \mathrm{M} \mathrm{H}_{2} \mathrm{SO}_{4}(\mathrm{~W})
\end{array}\right| \mathrm{SCE}
\end{aligned}
$$

where SCE stands for a saturated calomel electrode. The $\alpha-\left[\mathrm{H}_{2} \mathrm{SiMo}_{2}{ }_{2} \mathrm{Mo}_{10} \mathrm{O}_{40}\right]^{4-}$ in phase I or III was prepared by reduction of the oxidized form using ascorbic acid. The concentration $\left(C_{\mathrm{Ox}}^{\mathrm{III}}\right)$ of $\alpha-\left[\mathrm{SiMo}_{12} \mathrm{O}_{40}\right]^{4-}$ in phase III was changed stepwise by adding the acid in the concentrated solution or its solid form. The concentration dependence of the emf is shown in Fig. 3. Considering the experimental error of $\pm 1 \mathrm{mV}$, the experimental emf-values (open circles), on the whole, were found to show a Nernstian response, although somewhat deviations were observed at lower and higher concentrations. The solid line in Fig. 3 shows the Nernstian response with the slope of $15 \mathrm{mV}(=2.303$ $\times R T / 4 F)$ :

$$
e m f=\Delta_{\mathrm{II}}^{\mathrm{III}} \phi+\text { const. }=\Delta_{\mathrm{NB}}^{\mathrm{W}} \phi_{\mathrm{ox}}^{\circ}-\frac{R T}{4 F} \ln \frac{C_{\mathrm{ox}}^{\mathrm{II}}}{C_{\mathrm{ox}}^{\mathrm{III}}}+\text { const. }
$$

where $\Delta_{\mathrm{NB}}^{\mathrm{W}} \phi_{\mathrm{ox}}^{\circ}$ is the formal potential for the transfer of $\alpha-\left[\mathrm{SiMo}_{12} \mathrm{O}_{40}\right]^{4-}$ at the NB/W interface. Thus, at moderate concentrations $\left(0.4 \mathrm{mM}<C_{\mathrm{ox}}^{\mathrm{III}}<2 \mathrm{mM}\right)$, the NB/W

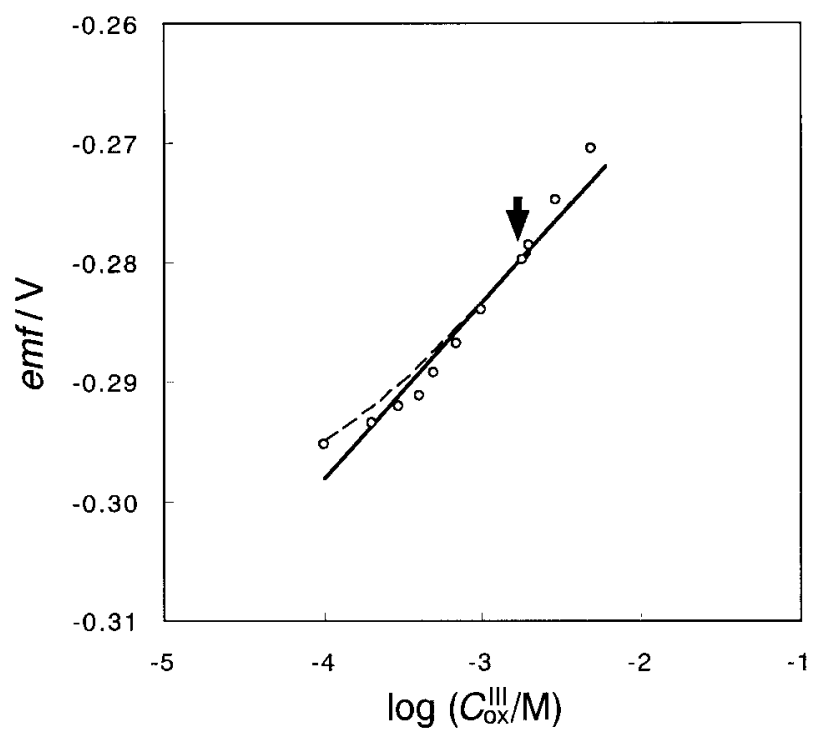

Fig. 3 Dependence of the emf of cell $\mathrm{B}$ on $\log C_{\text {ox }}^{\text {III }}$ The solid line is the Nernstian response with a slope of $15 \mathrm{mV}$; the dashed line is the calculated values of the mixed ion-transfer potential. With the concentration $\left(C_{\mathrm{ox}}^{\mathrm{III}}=1.8 \mathrm{mM}\right)$ indicated by the arrow, the proposed reference electrode is prepared. 
interface between phases II and III responds to $\alpha$ - $\left[\mathrm{SiMo}_{12} \mathrm{O}_{40}\right]^{4-}$ in a virtually reversible manner. Accordingly, the proposed reference electrode should be prepared under these conditions (e.g., $C_{\mathrm{ox}}^{\mathrm{III}}=1.8 \mathrm{mM}$ ). The deviation from the Nernstian response at lower concentrations $\left(C_{\mathrm{ox}}^{\mathrm{III}}<0.4 \mathrm{mM}\right)$ may be ascribed to the interference from the reduced form $\left(\alpha-\left[\mathrm{H}_{2} \mathrm{SiMo}_{2}{ }_{2-}\right.\right.$ $\left.\left.\mathrm{Mo}_{10} \mathrm{O}_{40}\right]^{4-}\right)$, which has the ion-transfer potential almost identical with the oxidized form $\left(\alpha-\left[\mathrm{SiMo}_{12} \mathrm{O}_{40}\right]^{4-}\right)$ as shown above. The potential difference of such a NB/W interface should be elucidated in terms of the mixed ion-transfer potential $\left(\Delta \phi_{\text {mix }}\right) \cdot{ }^{13-16}$ The dashed line in Fig. 3 shows the relative change of calculated $\Delta \phi_{\text {mix }}$ values based on the proposed theory ${ }^{13}$, which are in harmony with that of the experimental values. In the calculation of $\Delta \phi_{\text {mix }}$ the reported value ${ }^{17}$ of $D^{N B}=1.14 \times 10^{-6}$ $\mathrm{cm}^{2} \mathrm{~s}^{-1}$ was employed for the diffusion coefficients of the oxidized and reduced forms in NB. Their diffusion coefficients in $\mathrm{W}$ were assumed to be $D^{\mathrm{W}}=2.07 \times D^{\mathrm{NB}}$ $($ Walden rule $)=2.36 \times 10^{-6} \mathrm{~cm}^{2} \mathrm{~s}^{-1}$. Based on the present calculation, the theoretical deviation from the Nernstian response is only $0.2 \mathrm{mV}$ at $C_{\mathrm{ox}}^{\mathrm{III}}=1.8 \mathrm{mM}$. The deviation from the Nernstian response at higher concentrations $\left(C_{\text {ox }}^{\text {III }}>2 \mathrm{mM}\right)$ is most possibly ascribed to the protonation effect ${ }^{17}$ due to the increase in the acidity of phase III which would have been caused by addition of the acid form of the heteropolyanion.

\section{Ion-transfer voltammetry of the transfer of hydrophilic inorganic anions}

In order to examine the characteristics of the heteropolyanion reference electrode, voltammetric measurements were performed for the transfer of $\mathrm{X}^{-}\left(=\mathrm{Br}^{-}\right.$, $\mathrm{I}^{-}, \mathrm{SCN}^{-}, \mathrm{NO}_{3}^{-}$, and $\left.\mathrm{ClO}_{4}^{-}\right)$using the following cell:

I

$$
\mathrm{Pt} \mid \begin{array}{c|c}
1.8 \mathrm{mM} \alpha-\left[\mathrm{SiMo}_{12} \mathrm{O}_{40}\right]^{4-} & 0.3 \mathrm{mM} \\
0.2 \mathrm{mM} & \alpha-(\mathrm{THexA})_{4}\left[\mathrm{SiMo}_{12} \mathrm{O}_{40}\right] \\
\alpha-\left[\mathrm{H}_{2} \mathrm{SiMo}_{2} \mathrm{Mo}_{10} \mathrm{O}_{40}\right]^{4-} & 2.0 \mathrm{mM} \mathrm{Span}{ }^{\circledR} 20 \\
0.1 \mathrm{M} \mathrm{H}_{2} \mathrm{SO}_{4}(\mathrm{~W}) & 0.02 \mathrm{M} \mathrm{THexATPB}(\mathrm{NB})
\end{array}
$$

\begin{tabular}{|c|c|c|}
\hline III & IV & \\
\hline $\begin{array}{c}0.5 \mathrm{M} \mathrm{Li}_{2} \mathrm{SO}_{4} \\
0.5 \mathrm{mM} \mathrm{X}^{-} \\
(\mathrm{W})\end{array}$ & $\begin{array}{c}0.5 \mathrm{M} \mathrm{Li}_{2} \mathrm{SO}_{4} \\
0.1 \mathrm{M} \mathrm{LiCl} \\
(\mathrm{W})\end{array}$ & $\mathrm{AgCl} / \mathrm{Ag}$ \\
\hline
\end{tabular}

The NB/W interface (indicated by an asterisk) between phases II and III is to be tested. The transferring ion, $\mathrm{X}^{-}$, was added to phase III as the lithium or sodium salt. To avoid appearance of a current maximum, $\operatorname{Span}^{\circledR} 20$ (sorbitan monolaurate, Wako) was added to the NB phase. ${ }^{22}$ Phase III was contacted to phase IV through a salt bridge containing $0.5 \mathrm{M} \mathrm{Li}_{2} \mathrm{SO}_{4}$.

A typical cyclic voltammogram is shown in Fig. 4. A well-defined wave for the transfer of $\mathrm{NO}_{3}^{-}$was observed around $-0.6 \mathrm{~V}$. At less negative potential (around $-0.25 \mathrm{~V}$ ), a reversible wave for the transfer of $\alpha-\left[\mathrm{SiMo}_{12} \mathrm{O}_{40}\right]^{4-}$ (ref. 17) also appeared. Thus, the high-

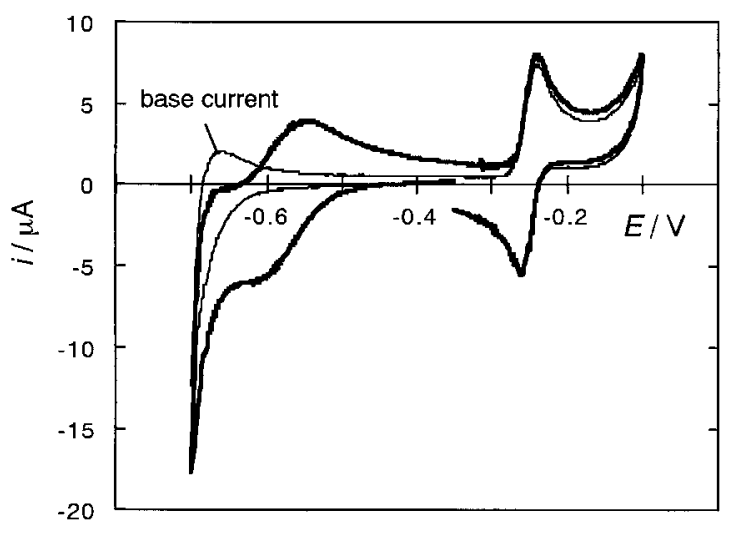

Fig. 4 Cyclic voltammogram of the transfer of $0.5 \mathrm{mM} \mathrm{NO}_{3}{ }^{-}$at the NB/W interface $\left(\right.$ area $\left.=0.045 \mathrm{~cm}^{2}\right)$. The cyclic potential scan was applied from $0.35 \mathrm{~V}$ in the cathodic direction at a rate of $30 \mathrm{mV} \mathrm{s}^{-1}$.

er potential region $(c a .0 .2 \mathrm{~V})$ in the potential window was spoiled by the heteropolyanion transfer, but the potential window of $c a$. $0.4 \mathrm{~V}$ still remained to be available in the lower potential region. For anions other than $\mathrm{NO}_{3}^{-}$, well-defined waves due to their transfers were also observed in the potential window.

The wave of the transfer of $\mathrm{X}^{-}$showed the characteristics of a reversible wave. The peak separation ( $c a .60$ $\mathrm{mV}$ at $30 \mathrm{mV} \mathrm{s}^{-1}$ ) agreed well with the theoretical value (i.e., $57 \mathrm{mV}$ ) for a reversible wave. Accordingly, the midpoint potential, $E_{\text {mid }}$, between the cathodic and anodic peak potentials can be assumed to be the reversible half-wave potential, $\left(E_{1 / 2}^{\mathrm{r}}\right)$, that is given by ${ }^{5}$

$$
E_{1 / 2}^{\mathrm{r}}=\Delta \Delta_{\mathrm{NB}}^{\mathrm{W}} \phi_{\mathrm{ox}}^{\circ}+\frac{R T}{z F} \ln \frac{\gamma^{\mathrm{NB}}}{\gamma^{\mathrm{W}}}+\frac{R T}{z F} \ln \frac{\sqrt{D^{\mathrm{W}}}}{\sqrt{D^{\mathrm{NB}}}}+\Delta E_{\mathrm{ref}}
$$

where $z$ is the ionic valence (here, $z=-1$ ), $\gamma^{\mathrm{W}}$ and $\gamma^{\mathrm{NB}}$ are the activity coefficients of the transferring ion in $\mathrm{W}$ and $\mathrm{NB}$, respectively, and $\Delta E_{\text {ref }}$ is the constant which is determined only by the reference electrode system employed.

The value of $\Delta E_{\text {ref }}$ was determined from the $E_{1 / 2}^{\mathrm{r}}$-value $(=-0.257 \mathrm{~V})$ of $\alpha-\left[\mathrm{SiMo}_{12} \mathrm{O}_{40}\right]^{4-}$, which was reproducible within the experimental error of $\pm 4 \mathrm{mV}$ (95\% confidence limit). According to the previous study ${ }^{17}$, the $E_{1 / 2}^{\mathrm{r}}$ of the simple transfer of $\alpha-\left[\mathrm{SiMo}_{12} \mathrm{O}_{40}\right]^{4-}$ is also given by Eq. (6) with $z=-4$. The value of $\Delta_{\mathrm{NB}}^{\mathrm{W}} \phi_{\mathrm{ox}}^{\circ}$ for the polyanion was then reported to be $0.066 \mathrm{~V}$ on the basis of the assumptions that $\left(\gamma^{\mathrm{W}} / \gamma^{\mathrm{NB}}\right)=1^{23}$ and $\left(D^{\mathrm{W}}\right.$ $\left./ D^{\mathrm{NB}}\right)=2.07$ (Walden rule). In this study, we also used these assumptions to estimate $\Delta E_{\text {ref }}$ to be $-0.321 \mathrm{~V}$ for cell $\mathrm{C}$.

The stability of the heteropolyanion reference electrode was checked by pursuing the $E_{\text {mid }}$ 's for $\mathrm{I}^{-}$and $\alpha$ $\left[\mathrm{SiMo}_{12} \mathrm{O}_{40}\right]^{4-}$. As seen in Fig. $5 \mathrm{~A}$, the $E_{\text {mid }}$ 's of these ions remained constant $(< \pm 2 \mathrm{mV})$ for at least $6 \mathrm{~h}$, although their slight changes with time were observed, especially in the initial $10 \mathrm{~min}$. Thus, the present reference electrode exhibited comparatively high stability. 

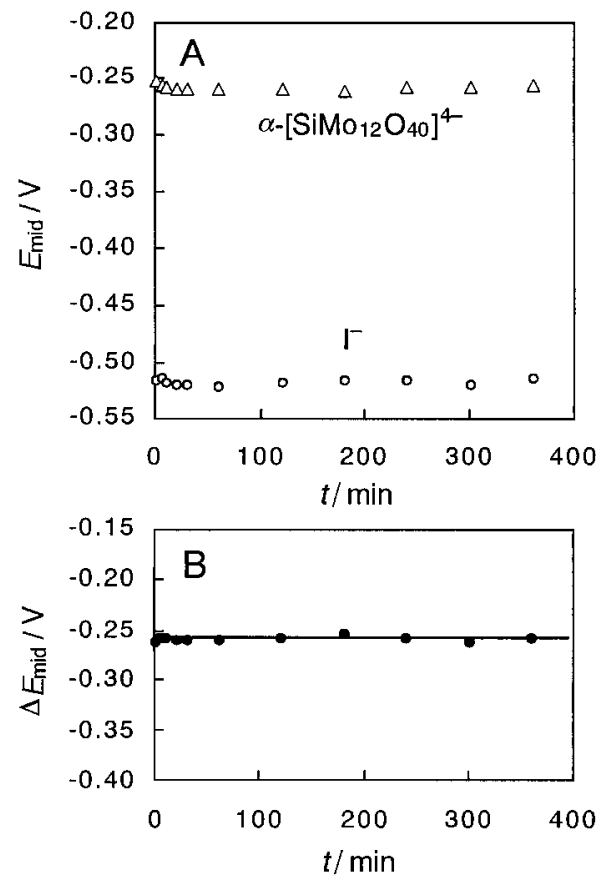

Eq. (6) with the estimated value of $\Delta E_{\text {ref }}(=-0.321 \mathrm{~V})$. However, in common with the L/L type reference electrodes prepared for ion-transfer voltammetry, some variability $(c a . \pm 5 \mathrm{mV})$ in the reference electrode potential was observed for different preparations. Accordingly, in order to obtain more accurate values of $\Delta_{\mathrm{NB}}^{\mathrm{W}} \phi^{\circ}$ (with an error less than $\pm 2 \mathrm{mV}$ ), the wave of $\alpha$ $\left[\mathrm{SiMo}_{12} \mathrm{O}_{40}\right]^{4-}$ was here employed as internal standard. Using Eq. (6), we can obtain the expression for $\Delta E_{\text {mid }}$ between $\mathrm{X}^{-}$and $\alpha-\left[\mathrm{SiMo}_{12} \mathrm{O}_{40}\right]^{4-}$ as

$$
\begin{aligned}
\Delta E_{\mathrm{mid}}= & E_{1 / 2}^{\mathrm{r}}-E_{1 / 2, \mathrm{ox}}^{\mathrm{r}}=\left(\Delta_{\mathrm{NB}}^{\mathrm{W}} \phi^{\circ}-\Delta_{\mathrm{NB}}^{\mathrm{W}} \phi_{\mathrm{ox}}^{\circ}\right)-\frac{R T}{F} \ln \frac{\gamma^{\mathrm{NB}}}{\gamma^{\mathrm{W}}} \\
& +\frac{R T}{4 F} \ln \frac{\gamma_{\mathrm{ox}}^{\mathrm{NB}}}{\gamma_{\mathrm{ox}}^{\mathrm{W}}}-\frac{R T}{F} \ln \frac{\sqrt{D^{\mathrm{W}}}}{\sqrt{D^{\mathrm{NB}}}}+\frac{R T}{4 F} \ln \frac{\sqrt{D_{\mathrm{ox}}^{\mathrm{W}}}}{\sqrt{D_{\mathrm{ox}}^{\mathrm{NB}}}}
\end{aligned}
$$

In this equation the subscript "ox" represents $\alpha$ $\left[\mathrm{SiMo}_{12} \mathrm{O}_{40}\right]^{4-}$, and no subscript $\mathrm{X}^{-}$. Since the value of $\Delta_{\mathrm{NB}}^{\mathrm{W}} \phi_{\mathrm{ox}}^{\circ}$ is known to be $0.066 \mathrm{~V}^{17}$, the value of $\Delta_{\mathrm{NB}}^{\mathrm{W}} \phi^{\circ}$ for $\mathrm{X}^{-}$can be obtained from $\Delta E_{\text {mid }}$ using Eq. (7) provided that the terms concerning $\gamma$ and $D$ are evaluated. The activity coefficients of $\mathrm{X}^{-}$were estimated by Davies' extended equation ${ }^{24}$ of the Debye-Hückel theory, and the term $-(R T / F) \ln \left(\gamma^{\mathrm{NB}} / \gamma^{\mathrm{W}}\right)$ was then calculated to be $0.004 \mathrm{~V}$. The term $-(R T / F) \ln \left(\sqrt{D^{\mathrm{W}}} / \sqrt{D^{\mathrm{NB}}}\right)$ was calculated to be $-0.009 \mathrm{~V}$ based on the assumption of $\left(D^{\mathrm{W}} / D^{\mathrm{NB}}\right)=2.07$ (Walden rule). The remaining two terms for the heteropolyanion are as described above. Finally, the value of $\Delta_{\mathrm{NB}}^{\mathrm{W}} \phi^{\circ}$ can be given by $\Delta_{\mathrm{NB}}^{\mathrm{W}} \phi^{\circ}$ $=\Delta E_{\text {mid }}+0.069($ in $\mathrm{V})$. Table 1 shows the values of $\Delta_{\mathrm{NB}}^{\mathrm{W}} \phi^{\circ}$ thus-calculated for the inorganic anions. In Table 1 are also shown the standard Gibbs energies $\left(\Delta G_{\mathrm{tr}}^{\circ} \mathrm{NB} \rightarrow \mathrm{W}\right)$ of their transfers at the NB/W interface being related to $\Delta_{\mathrm{NB}}^{\mathrm{W}} \phi^{\circ}$ as $\Delta G_{\mathrm{tr}}^{\circ}{ }^{\circ} \mathrm{NB} \rightarrow \mathrm{W}=-z F \Delta_{\mathrm{NB}}^{\mathrm{W}} \phi^{\circ}$, which are compared with some literature values. ${ }^{10,25-27}$ The present values have been found to coincide best with those reported by Koryta et al. ${ }^{25}$ The literature values in ref. 26 are negatively larger by $1-5 \mathrm{~kJ} \mathrm{~mol}^{-1}$ than the present ones.

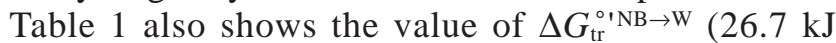
$\mathrm{mol}^{-1}$ ) for $\mathrm{TBA}^{+}$, which has been determined in a similar manner with the present system. This value differs somewhat from Koryta et al.'s value $\left(24.0 \mathrm{~kJ} \mathrm{~mol}^{-1}\right)^{25}$, but agrees well with another literature value $(26.5 \mathrm{~kJ}$

Table 1 Standard potentials and Gibbs energies of transfer of some anions at the NB/W interface at $25^{\circ} \mathrm{C}$

\begin{tabular}{lccccccc}
\hline \multirow{2}{*}{ Ion } & \multirow{2}{*}{$\Delta_{\mathrm{NB}}^{\mathrm{W}} \phi^{\mathrm{o}} / \mathrm{V}\left(\Delta E_{\text {mid }} / \mathrm{V}\right)$} & \multicolumn{5}{c}{$\Delta G_{\mathrm{tr}}^{\circ \mathrm{N} B} \rightarrow \mathrm{W} / \mathrm{kJ} \mathrm{mol}^{-1}$} \\
\cline { 3 - 7 } & & This study & Ref. 10 & Ref. 25 & Ref. 26 & Ref. 27 \\
\hline $\mathrm{Br}^{-}$ & -0.288 & $(-0.357)$ & -27.8 & -30 & -28.4 & -32.8 & -30.5 \\
$\mathrm{I}^{-}$ & -0.191 & $(-0.260)$ & -18.4 & -18 & -18.8 & -20.3 & -19.5 \\
$\mathrm{SCN}^{-}$ & -0.164 & $(-0.233)$ & -15.8 & & & -17.9 & -16.5 \\
$\mathrm{NO}_{3}^{-}$ & -0.261 & $(-0.330)$ & -25.2 & -26 & & -27.9 & -26.6 \\
$\mathrm{ClO}_{4}^{-}$ & -0.082 & $(-0.151)$ & -7.9 & -5 & -8.0 & -9.0 & -7.4 \\
$\mathrm{TBA}^{+}$ & $-0.277^{\mathrm{b}}$ & $(-0.336)$ & 26.7 & & 24.0 & & \\
\hline
\end{tabular}

a. Calculated from the reported values of $\Delta_{\mathrm{NB}}^{\mathrm{W}} \phi^{\circ}$. b. Determined in a similar manner, but with $\Delta_{\mathrm{NB}}^{\mathrm{W}} \phi^{\circ}=\Delta E_{\text {mid }}$ +0.059 (in V). 
$\left.\mathrm{mol}^{-1}\right) .{ }^{28}$

In conclusion, the proposed heteropolyanion reference electrode appears promising for voltammetric studies of the transfer of ions with fairly negative iontransfer potentials.

\section{References and Notes}

1. J. Koryta, Electrochim. Acta, 24, 293 (1979); 29, 445 (1984); 33, 189 (1988).

2. H. H. Girault and D. J. Schiffrin, in "Electroanalytical Chemistry, Vol. 15”, ed. A. J. Bard, pp. 1-141, Marcel Dekker, New York, 1989.

3. M. Senda, T. Kakiuchi and T. Osakai, Electrochim. Acta, 36, 253 (1991).

4. A. G. Volkov and D. W. Deamer (ed.), "Liquid-Liquid Interfaces, Theory and Methods", CRC Press, Boca Raton, 1996.

5. T. Kakutani, T. Osakai and M. Senda, Bull. Chem. Soc. Jpn., 56, 991 (1983).

6. A silver/silver tetraphenylborate internal reference electrode which is available in 1,2-dichloroethane has been reported in D. J. Clarke, D. J. Schiffrin and M. C. Wiles, Electrochim. Acta, 34, 767 (1989).

7. M. Senda, T. Kakutani and T. Osakai, Denki Kagaku, 49, 322 (1981).

8. P. Vanysek, J. Electroanal. Chem., 121, 149 (1981).

9. B. Hundhammer, T. Solomon and B. Alemayehu, J. Electroanal. Chem., 135, 301 (1982).

10. S. Kihara, M. Suzuki, K. Maeda, K. Ogura and M. Matsui, J. Electroanal. Chem., 210, 147 (1986).

11. B. Hundhammer and T. Solomon, J. Electroanal. Chem., 157, 19 (1983).
12. T. Osakai, T. Kakutani, Y. Nishiwaki and M. Senda, Anal. Sci., 3, 499 (1987).

13. T. Kakiuchi and M. Senda, Bull. Chem. Soc. Jpn., 57, 1801 (1984).

14. T. Kakiuchi, I. Obi and M. Senda, Bull. Chem. Soc. Jpn., 58, 1636 (1985).

15. S. Kihara and Z. Yoshida, Talanta, 31, 789 (1984).

16. S. Kihara, M. Suzuki, K. Ogura, O. Shirai and M. Matsui, Bunseki Kagaku, 39, 661 (1990).

17. T. Osakai, S. Himeno and A. Saito, J. Electroanal. Chem., 302, 145 (1991).

18. R. Massart, Ann. Chim., 3, 507 (1968); 4, 285 (1969).

19. J. P. Launay, R. Massart and P. Souchay, J. Less-Common Metals, 36, 139 (1974).

20. T. Osakai, S. Himeno and A. Saito, Bull. Chem. Soc. Jpn., 64, 1313 (1991)

21. $E_{\mathrm{mid}} \equiv\left(E_{\mathrm{pa}}+E_{\mathrm{pc}}\right) / 2 ; E_{\mathrm{pa}}$ and $E_{\mathrm{pc}}$ being anodic (positive-current) and cathodic (negative-current) peak potentials.

22. S. Sawada, T. Osakai and M. Senda, Bunseki Kagaku, 45, 1045 (1996).

23. This assumption is inevitable, because there is no reliable method for evaluating the activity coefficient of the multivalent heteropolyanion.

24. C. W. Davies, J. Chem. Soc., 1938, 2093.

25. J. Koryta, P. Vanysek and M. Brezina, J. Electroanal. Chem., 75, 211 (1977).

26. T. Kakutani, Y. Nishiwaki and M. Senda, Bunseki Kagaku, 33, E175 (1984).

27. B. Hundhammer and S. Wilke, J. Electroanal. Chem., 266 , 133 (1989).

28. Calculated from the value of $\Delta_{\mathrm{NB}}^{\mathrm{W}} \phi^{\circ}(=0.275 \mathrm{~V})$ which was claimed by Z. Samec, V. Marecek and D. Homolka, Faraday Discuss. Chem. Soc., 77, 10 (1984).

(Received September 24, 1997) (Accepted November 26, 1997) 